\title{
Socio-technical analysis of Indonesian government e-procurement system implementation: barriers to enhance information transparency and accountability
}

\author{
Fitri, Amalia \\ Accounting Department, Faculty of Economics and Business, Universitas \\ Gadjah Mada, Indonesia
}

\begin{abstract}
E-governance has become increasingly important to deliver better public services, and increase public trust. With a specific focus on eprocurement and the issues of transparency and accountability this research investigates the role and barriers of information technology in enhancing information transparency and accountability to the public, using the actornetwork theory and notion of delegation approach. This research concludes that information technology was delegated to automate the procurement process to increase transparency, accountability and prevent fraud. However, barriers of eliteracy, lack of leadership, reluctance of implementation, and lack of infrastructure created obstacles to attain the goals. This infers that social and technical aspects are interrelated and empower each other to support the technology in enhancing information transparency and accountability. Enhanced collaborative approach between the developers and users in the application development and implementation should be taken on board to enhance e-procurement system implementation quality.
\end{abstract}

Keywords: e-procurement, transparency, accountability, actor-network theory, delegation, role, barriers

\section{Introduction}

\subsection{Research Background}

The Asian financial crisis in the late 1990s enforced Indonesian government to increase their public sector's transparency and accountability and gain a stable economic condition $(1,2)$. IT in public sector open new ways of public management through e-government to deliver better public services, enhance communication between citizens and government, and improve citizen participation which eventually increase citizen trust (3).

However, there are challenges specifically for developing countries, which lack of capability and integrity to conduct good government governance. Based on the Seventh Annual Globe eGovernment Survey 2002, Indonesia was ranked $94^{\text {th }}$ amongst the 197 countries assessed (4), 
due to the lack of infrastructure, political will, and competent human resources. This condition initiated Indonesia's government commitment to develop and implement e-government policy to "improve its relationship with citizens and the business sector through enhanced, costeffective, and efficient delivery of services, information and knowledge using IT" (5, p. 483). One of Indonesia's e-government reform initiatives was to improve public spending efficiency through public e-procurement system (1).

\subsection{Research Justification and Research Questions}

Audit practice through check and balance becomes important to ensure social transparency and accountability, and also build public trust due to the increase of fraud, and corporate failures which intensified the demand for financial audit to establish good governance (6). Indonesia's ineffective public procurement system which incurs higher cost, leads to poor project performance. Moreover, the decentralization reform which gives the local government rights to disperse their decision making closer to the citizens, enhance the complexity in monitoring local procurement projects, which can create an uncompetitive business environment (7). The Indonesian government together with donors such as United States Agency for International Development (USAID) initiated the use of IT to facilitate e-procurement to enhance public service and access to Indonesia's rural areas. Despite the reform, Indonesia's public eprocurement has not been very successful due to socio-economic problems and digital divide (1, 7).

As IT represents a high risk in developing countries, its implementation to bridge the power distance between civil servants and the public must be monitored with higher norms and integrity $(8,9)$. Therefore, the relationship and network developed between the actors, social, and technical aspects involved in the government IT reform must be analyzed to understand the technology roles and challenges in accommodating the social demand and functions of information transparency and accountability. This research aims to analyze the role of IT in increasing e-procurement transparency and accountability using the actor network theory approach, to capture insights from technology developers and users and find out in the role of technology in fulfilling the e-procurement reform goals. In accordance with the research aims, below are the research questions:

1. How is the adoption of technology meant to enhance transparency and accountability for the e-procurement system's users?

2. What are the developer's insights about the barriers to transparency and accountability of the e-procurement system?

3. What are the users' insights about the barriers to the transparency and accountability of the eprocurement system?

\section{Literature Review}

\subsection{Information Transparency, Accountability, and Barriers in Indonesian e- Procurement}

As part of the national reform, in December 2004 World Bank and Organization for Economic Co-operation and Development-Development Assistance Committee (OECD DAC) together 
with developing countries (including Indonesia) and donors initiated the development of a set of tools and standards which guides the improvement and assessment of the national procurement systems (7). As part of the seven Flagship of The National Information Technology Board Republic of Indonesia, the Institution of Government Procurement Policy (IGPP) was established in 6 December 2007 under the Presidential Decree 106/2007 to create an efficient and effective spending of state budget, increase the human resource competency in eprocurement, and increase the capacity of IGPP as a policy and decision maker (10). In the first years of its implementation, 44 EPSU were established in 2008 and 2009, and in December 2010 this increased to 128 EPSU, which served 244 governmental institutions in 25 provinces across Indonesia (10).

IT has claimed to reduce the cost of collecting, distributing, and accessing government information thus provide government, citizens, and businesses greater access to information (11). In e-government, transparency is delivered through government proactive dissemination to release of government materials, public meeting and protection for whistleblowers $(11,12)$. In terms of accountability, IT enables greater citizen participation in politics and decision-making, increasing government responsibility to accommodate citizen aspiration and represent their views and interest in governing the nation (13). The effort to enforce transparency and accountability can be seen in India where e-government has facilitated online rural property records which increased the speed of record access and prevent bribery (14). The delivery of transparent data, the security of networks, confidentiality of information, and reliability and verifiability of information facilitates government accountability to the citizen (15). Citizen participation in e-government increases and is supposed to enhance process-based (responsiveness and information accessibility) and institutional-based trust (information transparency and government responsibility) (16). However, previous findings state that IT utilization does not guarantee the success of anti-corruption in transparency and accountability but may open new opportunities for corrupt behaviors instead (11). Internal resistance to transparency, creation of new means of corruption through IT, literacy rate, technology infrastructure, and digital divide are amongst the common barriers to e-government reform (2, $3)$.

\subsection{Actor Network Theory}

Actor Network Theory (ANT) has recently gained significant use in the field of information system research, emphasizing on the social-human-technology interaction $(17,18)$. Actors in forms of texts, technical artifacts, human skills, and institutions play a centre role in the networks and define the relationships between each other (19). Scientific and technological innovation, social patterns and organizational arrangements are to be stabilized through the network and interaction of human and non-human where conflicts and controversies can be overcome through translation of actors' interests, persuasion, and the enrolment of network and the mobilization of resources $(18,20,21)$. In this way, the scientific and technological innovation reflects the societies as they are shaped by the interaction of actants within the networks $(22,23)$. To establish a strong network and relation of actants, translation process involves power to stabilize social asymmetry and disputes between actors to align interests. The interaction process generates power, which is translated into a command resulting from each agent whom translates the power into their own desired outcome (20). Power persuades of translation through deformation of concepts and acts, which differ from diffusion as networks become more concentrated through iteration of actor-network relation. Society is held together by heterogeneous means of natural, technological, textual and topographical factors (23). Thus, 
it is true that organizations, social relations and technology are interrelated and often assumed able to support organization development (24) and possess political strength to stabilize and translate organization processes (25). The notion of delegation refers to transferring roles, values, intensions, and rules to technological artifacts or machines $(25,26)$. The roles and functions of humans are delegated to technology to create social durability (27) through the development of machines and technology, which embeds social and organizational role previously performed by human actors. This delegation was initiated to create social durability and discipline the society by tying humans to moral laws and build social morality.

\subsection{Linking ANT to Indonesian e-Procurement Transparency and Accountability}

The e-procurement system results from the interaction and collaboration of various stakeholders with different interests, which are aligned through the translation process. The technology and features translated within it were delegated to ensure safe and reliable procurement process and prevent any deviations, which were prone to occur in the manual procurement system. Referring to the politics of technology, (24) stated that politics are exercised based on the dominant society interest and represents the use of information in contextual terms, which denies the concept of technology neutrality. Thus, there may be unintended outcomes from the implementation such as users' resistant and users who do not confirm with the intended script inscribed in the technology, which questions the moral order of technology presupposed. Related to this, this research will refer to the notion of delegation and actor network theory to study the role of IT in Indonesian e-procurement system to establish transparent and accountable process, and also study the barriers in enforcing transparency and accountability for the public procurement.

\section{Research Methods}

Case study method allows researcher to focus on a specific situation to study various activities, which can combine data collection methods of interviews, archives, questionnaires and observations (28). Semi-structured interviews has been conducted with the developers and management of Indonesian Government e-Procurement System which are the e-Procurement Directory staff in the Institution of Government Procurement Policy (IGPP), and also with the users of e-procurement system: EPSU West Java Province and EPSU Central Kalimantan Province. Two staff from each organization was interviewed. The author gathered preliminary information from published materials from IGPP and EPSU website to understand about the project and research contexts. The researcher adopted the contact summary sheet method by (29) for the semi-structured interviews to validate the categorization of results based on the actor network theory used in the analysis. This enables the author to focus on the relevant information, which confirms the theoretical propositions used to design the case study and research scope (30).

\section{Results and Discussion}

\subsection{Actors and Networks}


To study the roles and barriers of technology in the e-procurement system, it is first important to identify the actors and their relationships in the e-procurement application development and implementation. In the global network, IGPP consist of policy and strategy development division, monitoring-evaluation and information system development division, human resources development division and law division, which collaborates to manage and develop the application. These divisions constantly collaborate and are in close contact with the EProcurement Services Unit (EPSU) in the local network to enhance coordination of implementation. IGPP also collaborates with donors and international organizations such as United States Agency for International Development (USAID), World Bank and Organisation for Economic Co-operation and Development (OECD) to develop the regulation and application of e-procurement (31). From 2007 until 2009 USAID through the Millennium Challenge Corporation-Indonesia Control of Corruption Project rewarded a grant to build the first five regional EPSU in five provinces in Indonesia (32). The collaborations and interactions within actors in the global network also occur in in the monitoring and evaluation of the eprocurement. Based on the interviews, IGPP periodically conduct meetings to gather feedbacks from users and related parties, and discuss about further application development. Some of the feedbacks suggest that the application should also provide services for e-catalogue, epurchasing, e-contract management, e-payment, and e-budgeting.

\subsection{Translation and Power}

The translation process involves all entities, which are enrolled into their identities and stabilized through project management, monitoring, and evaluation which control transactions between local and global network (20). The translation process begins with problematization in which the actors explain the problematical situation to other actors in the network to align interest through interessement and make them convinced to accept the idea of the situation, thus enrolling them into power and identities, also mobilising the actors which stabilize the network through the obligatory point of passage (20). In this project, IGPP communicate the urgency of e-procurement to governmental organization.

\subsection{Delegation and Durability: The adoption of Technology to Enhance Transparency and Accountability for the e-Procurement System}

The roles of human actors in procurement process are delegated to technology through the development of e-procurement application which embeds social and organizational role starting from procurement registration until result announcement. The interview results explain the developer's views that the role of IT is very important to make information more accessible and transparent throughout the whole e-procurement process. Previously, the announcements can only be accessed in the formal offices for a limited of time and accessible to limited people. Using IT, documents are uploaded into the system, encrypted and are only allowed to be uploaded in the specified time so it is difficult for the committee and participants to modify them. This e-procurement system also increases the independency of procurement committee from the head of institution and external parties, because sometimes there are pressures to pronounce a particular winner due to conflict of interest. The transparency of this system protects the procurement committee from such deviation. The users confirmed with the developers' insights on the importance of IT. IGPP also developed document security and eaudit application to increase public trust, document security, privacy through increased 
transparency and accountability. In this system, every user has to register online to be given an ID and password. E-audit and document security application plays a significant role to ensure the credibility and reliability of information disclosed to the public. Data security application secures and encrypts documents submitted by the vendors, which are secured by password and can only be open by the procurement committees and other verified users. This degree of document security and transparency enable immediate identification of irregularities in the system, and also immediate tracing of fraud. To support IT implementation, all EPSU personnel are certified, trained and officially employed to maintain their performance and integrity.

\subsection{Barriers to Transparency and Accountability of The e-Procurement System}

Despite of the importance of the applications, barriers of information transparency and accountability have prevented the full utility of the application. IGPP believe that the users view that technology is hard to implement which makes them reluctant to use this application. Thus, building trust through the transparency and accountability of the system will take great effort of training, and monitoring. From the developers' perspectives, there are no technical barriers, which prevent the application implementation to enhance transparency and accountability, but more of problems concerning human resources competency, leadership, and willingness to put some efforts in the improvement. Problems also occur in the e-audit implementation. The developers view that the progress of e-audit implementation has been slow due to the transition process and also in the human resource competency and infrastructure. Moreover, auditors lack of understanding of the e-procurement process and many of them are more convenient using the manual audit process. The problem of digital divide which leaves the majority of rural areas in Indonesia untouched by IT also create reluctance for users to implement this application. Moreover, since e-procurement is not yet compulsory, users tend to delay the implementation because they doubt whether this application will give them flexibility as in the manual system. Another problem is the lack of data interoperability and integration between the e-procurement application database with the institutions which issues legal documents required such as the tax office and law and attorney offices. Without interoperability the verification process is difficult and has to be done manually and is more prone to deviation.

\subsection{Discussion}

(27) argued that society is made durable; nothing is purely technological or social, as society is held together by heterogeneous means of natural and technological factors. Based on the case study, we can infer that the success of technology implementation does not only depend on the technical infrastructures and machines in the application, but also require the collaboration of competent and determined human actors to manage and support the technological roles in the organizations. Technology was delegated to substitute the role of human actors in the manual procurement process to prevent irregularities and fraud. Specifically, document security application and e-audit application were developed to increase information transparency, accountability and integrity of the application to increase public trust. IGPP have expressed the problematical procurement situation (problematization) to governmental organizations, aligned actor's interest and translated them into roles to achieve the desired outcome of the project. From the analysis, it is interesting to hear from the application developers and users that the main problems in the application implementation more relates to the organizational aspects of 
the users and staff such as lack of leadership to enforce implementation in the governmental organization, e-literacy, infrastructure and low level of public trust. These problems which are embedded in digital divide in developing countries (11) must be tackled with the deployment of technology, which provides access as well as training and engage users to participate in the application. Moreover, as greater connections between users, empowerment of citizens to participate in e-procurement and collaboration to promote the culture of transparency will enhance the social benefits of transparency (11). Regarding the heterogeneous actors involved in this project, we can infer that global network possess political interest and power over the local network. Even though governmental organizations are encouraged to be independent in the application management and implementation, problem of digital divide, and e-literacy increase the networks interdependence. These problematical situation shows lack of collaboration and restraint between actors in the global network, mostly the willingness of related parties to fully support the program.

Despite that the role of human actors in the manual procurement process were delegated into technology, the combination of organizational aspects and technical aspects remains crucial in the achievement of the goals. We can see that the application may not have hitches, but the implementation will struggle without the support of management and users' competency, leadership and trust. Lack of collaboration between human and non-human actors will create barriers to reach the desired outcome of technology delegation. What must be focused on are the social factors of user's acceptance, user's literacy, sufficient infrastructure, trust and leadership, which are the foundations of the application's success. This confirms previous research by $(11,33,34)$ that social determinants of users' acceptance, culture, education and trust determine the success of technology implementation.

\section{Conclusion}

This research identified the actors and networks involved in Indonesian e-procurement which assisted to study the role and barriers of information technology to enhance information transparency and accountability. The data was obtained from six interviews with e-procurement application developers and users and also supported by documentary data. Briefly explained, human and policy intervention, and different perceptions on the role of technology between developers and users creates obstacles in the application development and implementation; barriers of information transparency and accountability. In the translation process on eprocurement application, the lack of leadership from governmental organizations, reluctance to implementation, e-literacy of users, lack of infrastructures and lack of public trust create obstacles in the alignment of the actors' interest and enrolment into the project to implement the application. The role of information technology specifically the e-audit and document security application becomes crucial in preventing fraud, and maintaining the independence of procurement committees, also enhance transparency and accountability. The users and developers were overall satisfied with the e-procurement application and emphasized more in the obstacles of governmental organization leadership, users' e-literacy, lack of public trust, lack of interoperability of data, and lack of infrastructures. Due to the limitation of this research, there are some suggestions for further works. First, further research should also explore other IT reforms in the Indonesia ICT Flagship Program such as e-education, and e-budgeting. Moreover, a wider scope of research, which involves other actors such as donors, experts, 
academicians, and suppliers, will present richer findings to compare and contrast different insight.

\section{References}

1. World Bank. (2001). Indonesia country procurement assessment report: Reforming the public procurement system. Retrieved March 21, 2011, from http://siteresources.worldbank.org/INTINDONESIA/Resources/Procurement_Assessm ent.pdf.

2. Heeks, R. (2003). Reinventing government in the information age: International practice in IT-enabled public sector reform. New York: Routledge.

3. Tolbert, C., and Mossberger, K. (2006). The effects of e-government on trust and confidence in government. Public Administration Review, May-June.

4. Wahid, F. (2004) Lessons from e-government initiatives in Indonesia. Media Informatika, 2(2), 13-21.

5. Mirchadani, D., Johnson Jr, J., \& Joshi, K. (2008). Perspectives of citizens towards egovernment in Thailand and Indonesia: A multigroup analysis. Inf Sys Front, 10, 483497.

6. Power, M. (1997). The audit society: Rituals of verification. New York, Oxford university press.

7. OECD. (2007). Snapshot assessment of Indonesia's public procurement system. Retrieved March 21, 2011 from http://www.oecd.org/dataoecd/27/47/39254688.pdf

8. Ciborra, C. (2005). Interpreting e-government and development: Efficiency, transparency or governance at a distance? Inf Tech \& People, 18(3), 260-279.

9. Allen, A., Juillet, L., Paquet, G. and Roy, J. (2001). E-governance and government online in Canada: Partnerships, People and Prospects, Gov Inf Quarterly, 18, 93-104.

10. Institution of Government Procurement Policy (IGPP). (2010) Profil LKPP. Retreived May 262011 from http://www.lkpp.go.id/v2/profil_lkpp.pdf.

11. Bertot, J., Jaeger, P., \& Grimes, J. (2010). Using ICTs to create a culture of transparency: E-government and social media as openness and anti-corruption tools for societies. Gov Inf Quarterly, 27, 264-271.

12. Shim, D., and Eom, T. (2008). E-government and anti-corruption: Empirical analysis of international data. Int Journal of Public Adm, 31, 298-316.

13. Kumar, A. (2003). E-government and efficiency, accountability and transparency. EJISDZ, 12, 2, 1-5.

14. Bhatnagar, S. (2003). E-government and access to information. Global Corruption Report. Retreived June 62011 from http://unpan1.un.org/intradoc/groups/public/documents/apcity/unpan008435.pdf.

15. Welsch, E., and Hinnant, C. (2002). Internet use, transparency, and interactivity effects on trust in government. Proceedings of the 36th Hawaii International Conference on System Sciences (HICSS'03).

16. Welsch, E., Hinnant, C., and Moon, M. (2005). Linking citizen satisfaction with egovernment with trust in e-government. Journal of Public Adm Research and Theory, 15(1), 37-58.

17. Elbanna, B. (2003). The implications of the local configuration of a standard eprocurement system on the organisation power circuits. Presented in the $16^{\text {th }}$ Bled eCommerce Conference e-Transformation, Bled, Slovenis, June 9-11.

18. Latour, B. (1987) Science in Action. Cambridge: Harvard University Press. 
19. Stanforth, C. (2007). Using actor-network theory to analyze e-government implementation in developing countries. The Massachusetts Institute of Technology Information Technologies and International Development, 3(3), 35-60.

20. Callon, M. (1986). The sociology of an actor-network: the case of the electric vehicle. In: M, Callon., J, Law., \& A. Rip. (Eds.), Mapping the Dynamics of Science and Technology, Sociology of Science in the Real World (pp. 19-34). London: The Macmillan Press.

21. Law, J. (1992). Notes on a theory of actor-network: ordering, strategy and heterogeneity. Sys Practice, 5(4), 379-393.

22. Bijker, W. E., and J. Law, eds. (1992). Shaping technology/Building society: Studies in sociotechnical change. Cambridge, MA, MIT Press.

23. Law, J. (1999) After ANT: Complexity, Naming and Topology. In J, Law., \& J, Hassard. Actor Network Theory and After (pp. 1-14). Oxford: Blackwell.

24. Bloomfield, B.P. (1995). Power, machines and social relations: Delegating to information technology in the National Health Service. Organization, 2, (3-4), 489518.

25. Akrich, M. (1992). The De-Scription of technical Objects, in W. Bijker and J. Law (eds) Shaping technology/Building Society, 205-224, Cambridge, MA, MIT Press.

26. Latour, B. (1992). Where Are the Missing Massess?, in W. Bijker and J. Law (eds) Shaping Technology/Building Society, 225-258. Cambridge, MA, MIT Press.

27. Latour, B. (1991). Technology is Society Made Durable, in J. Law (ed.) A Sociology of Monsters: Essay on Power, Technology and Domination, 103-131.

28. Eisendhardt, K.M. (1989). Building theories from case study research. The Academy of Management Review, 14(4), 532-550.

29. Miles, M.B., \& Huberman, M. (1994). Qualitative Data Analysis: An Expanded Sourcebook $\left(2^{\text {nd }}\right.$ ed). Beverly Hills, CA: Sage Publishing.

30. Yin, R. (1994) Case study research: Design and methods (2nd ed.). Beverly Hills, CA, Sage Publishing.

31. Yulianto, A. (2010) Konsep Fungsi dan Implementasi Portal Pengadaan Nasional. Retreived August 62011 from http://www.lkpp.go.id/v2/files/content/file/ 29112010161242Andik\%20Yulianto-Konsep\%20Portal\%20Pengadaan\%20NasionalV1-3.pdf.

32. Arifiyadi, T. (2010) Bab III Konsep pengadaan secara elektronik (e-procurement) instansi pemerintah. Retreived August 62011 from http://www.lontar.ui.ac.id/login.jsp?requester=file?file=digital/ 135548.Analisis\%20hukum.pdf. [Accessed August 6 2011].

33. Jaeger, P. T., \& Matteson, M. (2009). E-government and technology acceptance: The implementation of Section 508 guidelines for e-government websites. Electronic Journal of E-Government, 7(1), 87-98.

34. Heeks, R. (2005) E-government as a carrier of context. Journal of Public Policy, 25, 51-74. 